DOI: $10.7819 /$ rbgn.v15i49.1357

Subject Area: Marketing

\title{
Gender Difference in the Perception of Guilt in Consumer Boycott
}

\author{
Diferença de Gênero na Percepção de Culpa no Boicote de Consumidores
}

Diferencia de Género en la Percepción de la Culpa en el Boicot de Consumidores

\author{
Breno de Paula Andrade Cruz ${ }^{1}$ \\ Ricardo José Marques Pires J $\mathbf{J r}^{2}$ \\ Steven Dutt Ross ${ }^{3}$
}

Received on June 28, 2012 / Approved on November 06, 2013

Editor in charge: João Maurício Gama Boaventura, Dr.

Evaluation Process: Double Blind Review

\begin{abstract}
In Brazil, studies on consumer boycott still feature some gaps, including theoretical ones. Our article aims to present the significant difference between male and female perception of guilt in the specific case of a multinational company which sells products in Brazil. To achieve that goal, the boycott motivations scale (KLEIN; SMITH; JOHN, 2004) was validated by means of 218 respondents from two universities located in the state of Rio de Janeiro. Using regression, a difference among genders was found based on one of the validation factors of the scale (perception of guilt). The results show that out of the four factors found by the Factorial Analysis, only the "perception of guilt" factor proved to be significant for the difference of means between
\end{abstract}

men and women $(\mathrm{p}<0.002)$. That implies that the women of our study sample felt guiltier than the men regarding boycott motivations. That empiric result makes our article relevant to the Marketing area. In addition, some historical, anthropological and psychological implications are presented in its last section. Understanding guilt and its relation with the social construction of woman in society is a required development to strengthen the empiric findings of our study.

Keywords: Consumer boycott. Gender. Boycott motivations.

\section{RESUMO}

Estudos no Brasil sobre boicote de consumidores ainda apresentam lacunas, inclusive teóricas. $\mathrm{O}$

1. Doctor of Business Administration by the Getúlio Vargas Foundation (FGV)

Professor of the Rural Federal University of Rio de Janeiro (UFRRJ). [brenocruz@ufrrj.br]

2. Psychology Student at the Brazilian Institute of Rehabilitation Medicine (IBMR).

Scientific Initiation Scholarship Holder of the Federal University of Rio de Janeiro (UFRJ) and the Rural Federal University of Rio de Janeiro (UFRRJ). [ricardo_marquesjr@hotmail.com]

3. Doctor of Production Engineering by the Fluminense Federal University (UFF)

Researcher at the Department of Public Policy Analysis (DAPP/FGV). [steven.ross@fgv.br]

Authors' address: Universidade Federal Rural do Rio de Janeiro, Instituto de Ciências Humanas e Sociais. Km 7, Estrada Rio-Santos CEP 23890-000 - Seropédica - RJ - Brasil 
objetivo deste artigo é apresentar a diferença significativa entre a percepção de culpa das mulheres em relação aos homens em um caso específico de uma empresa multinacional que comercializa produtos no Brasil. Para isso, validou-se a escala de motivaçóes para o boicote (KLEIN, SMITH, JOHN, 2004) a partir de 281 respondentes de duas instituições de ensino superior no estado do Rio de Janeiro e verificouse, por meio de uma regressáo, a diferença entre os sexos a partir de um dos fatores da validação da escala (percepção de culpa). Os resultados demonstram que dos quatro fatores encontrados na análise fatorial, apenas o fator "percepção de culpa" mostrou-se significativo na diferença das médias entre homens e mulheres $(\mathrm{p}<0,002)$. Isso significa compreender que mulheres se sentem mais culpadas que homens no que diz respeito às motivaçôes para boicote na amostra utilizada neste estudo. Esse resultado demonstra a relevância deste artigo para a área de Marketing. Além disso, alguns desdobramentos históricos, antropológicos e psicológicos são apresentados no final do artigo. Entender a culpa e a relação com a construção social da mulher mostrou-se um desdobramento necessário para dar robustez aos resultados empíricos encontrados nesta investigação.

Palavras-chave: Boicote de consumidores. Gênero. Motivaçóes para o boicote.

\section{RESUMEN}

Estudios hechos en Brasil sobre el boicot de consumidores aún presentan lagunas, incluso teóricas. El objetivo de este artículo es presentar la diferencia significativa entre la percepción de culpa de las mujeres en relación a los hombres en un caso específico de una empresa multinacional que comercializa productos en Brasil. Para ello, se ha validado la escala de motivación para el boicot (KLEIN; SMITH; JOHN, 2004) partiendo de 281 encuestados de dos instituciones de educación superior en el estado del Rio de Janeiro y se verificó, por medio de una regresión, la diferencia entre los sexos partiendo de uno de los factores de la validación de la escala (percepción de la culpa). Los resultados demuestran que de los cuatro factores encontrados en el Análisis Factorial, sólo el factor "percepción de la culpa" se mostró significativo el la diferencia de las medias entre hombres y mujeres $(\mathrm{p}<0,002)$. Ello significa c que las mujeres se sienten más culpable que los hombres con respecto a las motivaciones de boicot en la muestra utilizada en este estudio. Este resultado demuestra la relevancia de este artículo para el área de Marketing. Además, algunos desdoblamientos históricos, antropológicos y psicológicos son presentados al final del artículo. La comprensión y la relación con la construcción social de la mujer en la sociedad se mostraron como un desdoblamiento necesario para dar solidez a los resultados empíricos encontrados en esta investigación.

Palabras clave: Boicot de consumidores. Género. Motivación para el boicot.

\section{RATIONALE AND SIGNIFICANCE OF THE RESEARCH}

The various social, economic and cultural changes have helped researchers to (re)think both the locus of academic research and the research topics in the area of consumer behavior in Brazil. Consumer boycott ranks among the less discussed subjects and therefore features knowledge gaps. Cruz (2011) is the first study on that issue that analyzes the Brazilian context based on a sound theoretical background. The author conducted a thorough theoretical survey on the subject of consumer boycott related to Corporate Social Responsibility (CSR) and presented suggestions for future research in Brazil related to consumer boycott and CSR.

Empirical cases of boycotts have already been described in the past, in Brazil (CRUZ, 2013b). They address that issue from either a managerial point of view, or from an academic marketing perspective, treating boycotts as an act 
of voluntarily abstaining from buying a specific product or service as a way to reject a given company. It is precisely that definition of boycott, the act of voluntarily abstaining from buying a given product or service, that guides our study and it is based on the studies by Friedman (1999), Klein, Smith and John (2004), Soule (2009) and Cruz (2011, 2013a, 2013b).

After having analyzed a variety of research possibilities on that topic, from both a qualitative research and a quantitative research perspective, this study discusses an important relation in the theory of consumer boycotting: the influence of gender on boycotting. In international literature, some quantitative studies seek to relate consumer motivations to boycotting (KLEIN; SMITH; JOHN, 2004), or to relate demographic variables to the inclination of consumers to boycotting, such as Kalson (2005), Stolle, Hogge and Micheletti (2005), and Neilson (2010) who respectively analyzed the relation of boycotting with gender, age, and educational level of consumers. In the Brazilian context, Cruz (2013a) did not found any significant relationship between gender and boycott.

Boycotts depend not only on the economic conditions of consumers, but also on their psychosocial features. Boycott motivations vary according to personal motivations of consumers. Klein, Smith and John (2004) conducted a major study on boycotting which has been mentioned in quite a number of articles. Their study aimed to find out what motivated consumers to boycott a multinational company operating in the United States. More precisely, a factor analysis and a linear regression analysis yielded four different factors which, once analyzed together, define boycotting motivations, including: Perceived Boycott Effectiveness of Consumers, Perceived Self-Enhancement of Consumers, Counterarguments that inhibit Boycotting, and Purchasing Frequency.

In that study, the first factor that explains boycott motivations is called 'Boycott effectiveness'. However, its original name given by the authors was 'Make a difference', which was then changed to 'Boycott effectiveness' in the Handbook of Marketing Scales. If we analyze the three items that make up that factor, it seems that the term used in the Handbook is appropriate, which explains the translation into Portuguese in this study as 'Perceived boycott effectiveness of consumers'. The second factor found by Klein, Smith and John (2004) was Self-improvement, which is related to consumer guilt and influence of others. The third factor is characterized by items against boycotts, since consumers also take into account arguments that may lead them to give up their abstention from buying. The last factor was named 'Purchasing frequency' and analyzes the purchasing history of consumers.

Based on the study by Klein, Smith and John (2004), the aim of our article is to find out if the perception of guilt in men and women yields a significant difference. To do so, we used a validated scale in the Brazilian context. That objective has raised the research problem of our article: do women perceive themselves as being guiltier than men when boycotting a company? More specifically, we set the following objectives: (i) to translate the scale items and to build a questionnaire for an actual boycott case; (ii) to find the boycott scale motivation factors in the Brazilian context using factor analysis; (iii) to evaluate the (internal and external) reliability of the scale; (iv) to evaluate the validity of scale by means of the discriminant validity; (v) to test the difference of means hypothesis on the perception of guilt between men and women.

In addition to that brief introduction that describes the relevance of the subject of consumer boycott in the Brazilian context, this article contains four additional sections. The next section presents the theoretical framework of consumer boycott. The third section describes the methodological approach we chose to adapt the scale by Klein, Smith and John (2004) to the Brazilian context and the Difference of Means Test. The fourth section presents the findings of the scale validation process and the fifth section presents the theoretical and managerial implications of our study. 


\section{THEORETICAL BACKGROUND}

This section presents the theoretical approach to consumer boycott. It first presents the six types of boycotts described in the literature and how the issue has been addressed in the literature of the marketing area. After that, we describe the theoretical background that supports the research hypotheses of the 'Gender' variable and its relation to consumer boycott.

\section{I Consumer boycott}

The term boycott was first used around 1880 to designate retaliation organized by small merchants who had to deal with a big American farmer, Charles Boycott. The term boycott was used for the first time when the group of small merchants realized they could retaliate to his unreasonable demands by avoiding buying his products (SOULE, 2009).

The consumer act of abstaining from buying a product or service from a given company (FRIEDMAN, 1999; SOULE, 2009) is what differentiates that practice from other ones, such as social movements, demonstrations, or activist marches who seek to tarnish the reputation of a given company. Although boycotts are a less aggressive approach if compared to, e.g., marches organized by NGOs, company losses are still tangible.
In Brazil, people and especially marketing researchers commonly use the term 'boycott' to define acts of repudiation against companies. Cruz (2011) makes an important and relevant conceptual distinction between acts of repudiation and consumer boycott. The author introduces the term backlash as a form of repudiation, which includes boycotts. However, any given act of repudiation, such as demonstrations, is a backlash. It is by defining the concept of boycott that Cruz (2011) makes a difference between the terms so that boycott is understood as abstaining from buying a product or service from a given company.

Friedman (1999) states that boycotts depend on consumer motivations and can be classified in five types, according to his own typology: (i) economic, (ii) religious, (iii) minoritary (iv) ecological, and (v) labor boycott. Cruz (2013a) found that the translation alone of the term labor boycott does not takes into account the current context of organizations regarding the specific demands of company stakeholders and therefore expanded this type of boycott to social boycott, which includes aspects related to Corporate Social Responsibility. He also introduced a type of boycott that had never been addressed in the literature before - the relational boycott. Chart 1 shows the types of boycotts found in the literature, their main features, and their occurrences in Brazil. 


\begin{tabular}{|c|c|c|}
\hline Type & Main Features & Examples in Brazil \\
\hline $\begin{array}{l}\text { Economic } \\
\text { boycott }\end{array}$ & $\begin{array}{l}\text { Consumers avoid buying a product or service because they don't agree with } \\
\text { individual or market economic variables (e.g. price or monopole situation). }\end{array}$ & $\begin{array}{l}\text { BR gas stations in } \\
\text { Natal }(\mathrm{RN})- \\
\text { abusive pricing }\end{array}$ \\
\hline $\begin{array}{l}\text { Religious } \\
\text { Boycott }\end{array}$ & $\begin{array}{l}\text { Historically, religious groups have controlled their followers by means of ideologies } \\
\text { and beliefs. Boycotts are a way to achieve their goals. The most common ones are } \\
\text { aimed at films, soap operas, or ads containing inappropriate contents. }\end{array}$ & $\begin{array}{l}\text { Du Loren }- \text { ad } \\
\text { featuring a half-naked } \\
\text { model at the Vatican }\end{array}$ \\
\hline $\begin{array}{l}\text { Boycott by } \\
\text { or in favor of } \\
\text { minorities }\end{array}$ & $\begin{array}{l}\text { Actions conducted by a minority group (in relation to the company or consumers } \\
\text { in general) featuring peculiar and circumstantial goals when compared to other } \\
\text { forms of boycotts. Also conducted in favor of groups in vulnerable situations } \\
\text { (e.g., racial or homosexual segregation). }\end{array}$ & $\begin{array}{l}\text { Mc Donald's (World } \\
\text { Cup 2014) }\end{array}$ \\
\hline $\begin{array}{l}\text { Ecological } \\
\text { Boycott }\end{array}$ & $\begin{array}{l}\text { Organized when consumers perceive that a company is acting in a harmful or } \\
\text { abusive way towards the environment. Consumers are generally influenced by } \\
\text { NGOs working for the preservation of the planet. }\end{array}$ & $\begin{array}{l}\text { Arezzo - Pele Mania } \\
\text { Collection }\end{array}$ \\
\hline $\begin{array}{l}\text { Social } \\
\text { Boycott }\end{array}$ & $\begin{array}{l}\text { Consumers boycott a company because they do not agree with disadvantageous } \\
\text { or unfair practices towards employees and other direct or indirect partners, i.e., } \\
\text { that kind of boycott includes variables or situations that are also related to CSR, } \\
\text { such as corruption, supply chain labor conditions and organizational culture and } \\
\text { climate. }\end{array}$ & Zara \\
\hline $\begin{array}{l}\text { Relational } \\
\text { boycott }\end{array}$ & $\begin{array}{l}\text { Consumers abstain from buying from a given company when the relationship } \\
\text { between the parties is considered flawed by consumers. Relational boycotts are an } \\
\text { act of punishment towards the company and result of delays, defective products, } \\
\text { and inefficient company service. }\end{array}$ & $\begin{array}{l}\text { Tok Stok and } \\
\text { Ponto Frio }\end{array}$ \\
\hline
\end{tabular}

CHART 1 - Types of boycotts in literature

Source: Based on Friedman (1999), Cruz (2013a; 2013b)

Empirical cases demonstrate the strength and importance of boycotts and how seriously companies take them. For instance, due to boycott pressure from American and Canadian universities, Coca-Cola had to revise its operations in Colombia regarding the violation of human rights, since Coca-Cola contracts and products had been banned from 20 universities in those two countries (KREYRE 2006 apud PALAZZO; BASU, 2007, p. 338-339). Shell lost between 10 and 15 million dollars due to damages in 1999 because consumers boycotted the company because of the Brent Spar case (KNIGHT, PRETTY, 2000). Greenpeace found that Shell lost $7 \%$ of its market share since it decided not to join the Kyoto Protocol (AAKER, 2004). However, there are no studies comparing boycott efficiency from the perspective of consumers and of tangible or intangible returns.

The research by Klein, Smith and John (2004) published by the Journal of Marketing is one of the main studies that helps understanding the reasons why consumers decide to participate in boycotts. The authors focused on a European multinational company with operations in the United States to find out what could influence consumers to boycott that company. They identified 13 items that were clustered into four dimensions by means of a factor analysis. Those clustered items, plus some additional ones that have been suggested by other experts, are presented below.

Other studies used a quantitative analysis, e.g., to explore demographic variables vs. consumer boycott. Neilson (2010) and Stolle, Hogge and Micheletti (2005), e.g., found that women are more inclined to consume politically than men - boycotting being a form of political consumption. According to Neilson (2010), at a significance level of $5 \%$, women show a more favorable behavior towards boycotting, exceeding men by approximately $10 \%$. Barda and Sardianou (2010) also found that women are more inclined to boycott than men. 
Income is another demographic variable that some authors analyzed crossing it with the 'Consumer boycott' variable. According to Neilson (2010), consumer income is positively correlated with boycotting. In the sample analyzed by that author, that variable positively influences boycotting, i.e., the higher the educational level of consumers, the greater the chances that they would join a boycott if they would disagree with the actions of a given company. The next section expands the discussion about the demographic 'Gender' variable.

\subsection{Evidence of gender differences in consumer boycott studies}

Some authors found that gender may influence consumer boycotting, such as Barda and Sardianou (2010) who analyzed the behavior of Greek consumers and their intention to boycott during the financial crisis in Greece in 2010. They reported that women proportionally took more part in boycotts than men. Taking into account the field of operations of the analyzed company (supermarkets), that finding might be explained by the fact that woman more often shop in supermarkets than men. However, the authors controlled that variable so that the purchasing frequency effect wouldn't distort the results. Still, women were more inclined to boycotting than men.

That empirical situation presented by Barda and Sardianou (2010) is not characteristic of Greek women or of the fact that (most) women are in charge of purchasing food products for their families. Other studies also show that women are more inclined to consume politically than men (NEILSON, 2010; STOLLE, HOGGE, MICHELETTI, 2005), boycotting being are a form of political consumption. According to Neilson (2010), women show a more favorable behavior towards boycotting, exceeding men by approximately $10 \%$.

On the other hand, the results of surveys conducted in Sweden, Canada and Belgium by Stolle, Hogge and Micheletti (2005) show that women are more likely to boycott or to buycott ${ }^{1} 1$ than man by $16 \%(\mathrm{p}<.001)$. To avoid the counter-argument that women more often go to malls or more often buy food and groceries than men, the authors controlled those variables. Nevertheless, a significant difference between genders was found.

Klein, Smith and John (2004) reported the same relation and found that women are inclined to that type of action than men. In a sample of 1216 consumers, women showed to be readier to boycott than men by $6 \%(\mathrm{p}<.01)$. The fact that women are traditionally more concerned and take greater care of their families causes them to be more predisposed to join boycotts (as a form of political consumption), since they analyze complex situations or circumstances quite thoroughly (NEILSON, 2010), as opposed to men, who don't perform that kind of analysis.

An empirical evidence of the organization and tendency of women to boycott that had a repercussion in the United States in 2010 and 2011 was the decision to boycott products from companies that impact the health of consumers (KALSON, 2005). The Girlcott group - the name is a combination of the words girl and boycott - shows the importance of women in that type of decision and political engagement for a cause. Girlcott encourages women to say no to cancer-causing products and to buy healthy products instead, which are safer for the health of consumers in the long run (THE GIRLCOTT, c2009). In practice, that group has started both a boycott and a backlash.

A study conducted in Brazil in 2013 interviewed 240 respondents and applied a $2 \times 2 \times 2$ factorial experiment (CRUZ, 2013a) to test hypotheses regarding consumer gender vs. 'Intention to Boycott' (IB) and 'Perceived Boycott Effectiveness' (PBE) variables. However, regarding the 'gender' variable, the hypothesis that women show higher IB and PBE than men was rejected. The product segment chosen by the study (computers) might have been a bit more distant from consumer reality than the footwear segment 
(such as Nike, used in our research). In addition to that, experiments do not aim to generalize results, allowing us to study the influence of the 'gender' variable on boycotts.

\section{METHODOLOGY}

This item presents the methodological approach chosen to adapt and validate the scale by Klein, Smith and John (2004) so that it may be used in the Brazilian context. The following items describe the translation and reverse translation processes, the development of the data collection tool and its pretest, and the scale validation process.

\section{I Translation and reverse translation of scale items}

The study by Klein, Smith and John (2004) describes what motivates consumers to boycott a company and presents four factors related to consumer boycott, including boycott effectiveness, i.e., how consumers assess the effectiveness of their participation in boycotts. The three items validated by Klein, Smith and John (2004), which translate into how consumer perceive the effectiveness of boycotts, are presented in Chart 2. That translation process was adopted for all items of the other dimensions of the study by Klein, Smith and John (2004) as well.

\begin{tabular}{|l|l|}
\hline 'Boycott effectiveness' scale items & Score \\
\hline Boycotts are an effective means to make a company change its actions. & 0.851 \\
\hline Everyone should take part in the boycott because every contribution, no matter how small, is important. & 0.753 \\
\hline By boycotting, I can help change Bremmer's decision. & 0.762 \\
\hline
\end{tabular}

CHART 2 - Scale items of boycott effectiveness (Klein, Smith, and John, 2004, p. 101)

Source: the authors.

After we decided to use that scale in the Brazilian context, we had to translate it from English into Portuguese. An expert in developing and adapting scales helped us to select four postgraduates in both English and Portuguese to translate and reverse translate the scale.

After that, another expert in building scales made us aware of a chapter by DeVellis (2003) which resulted in a small adjustment of one of the scale items to make it clearer to respondents that they had to express themselves about it. According to that author, a well-formulated item should force respondents to take up a stance over it and we therefore added 'very effective' to the first scale item. The same expert suggested that the second scale item should be divided into two items - which coincided with the translation of the first expert, who used two separate sentences. However, the other language experts did not agree in splitting the item.

As can be seen in the scale items, instead of using the word 'boycott', we used its definition, i.e., 'abstain from buying', which makes an important difference in the Brazilian context, since it helps to avoid confusing boycott with backlash. As previously noted by Cruz (2013b), boycotts are a form of repudiation, just like other forms of repudiation, such as protests against some specific company actions (demonstrations, using social media, etc.). To limit the term boycott to its theoretical definition, i.e., the act of abstaining from buying, we decided to remove the term boycott and use its definition instead.

\subsection{Data collection tool development and pretest}

After the translation and adaptation of the consumer boycott motivations scale, a data collection tool was created and pretested by consumers of a multinational sporting goods company operating in Brazil. The first version of the questionnaire contained the eleven scale items by Klein, Smith and John (2004) and a twelfth item created by the authors to analyze the case situation, including the possibility of consumers 
abstaining from buying. The case presented to readers involved the multinational company Nike, which has been accused of employing child labor in their supply chain. Thirty-seven randomly applied pretest questionnaires, as well as feedback from respondents helped us to develop the final version of the questionnaire.

The purpose of the pretest at this stage of the research was to find out if we would obtain similar results as those published by Klein, Smith and John (2004) if we performed the factor analysis using our items. Cronbach's alpha resulted in 0.453 for the 12 items and did not lie within the acceptable range - i.e., between 0.60 and 0.70 (HAIR et al., 2005). The scale used in the pretest was thus not statistically reliable. We decided to remove three items and Cronbach's alpha then resulted in 0.68. Removing those three items produced three factors that explained $72 \%$ of the variability. A KMO Test and a Bartlestt Test were performed to validate the factor analysis during the pretest. Although the KMO test did not pass, it produced a result close to the acceptable value of 0.60. On the other hand, the Bartlestt test showed that the sample was sufficient, i.e., significant.

Pretest results (after removal of three items) revealed that another verification item could be included in Factor 1, since the 'guilt' feature had become evident in both items that make it up and partially differed from the study by Klein, Smith and John (2004). It seemed possible that in the Brazilian context, that factor could be expressed differently than in the American context and we therefore included another item after having taken advice from two experts in consumer behavior and quantitative methods. The same occurred with Factor 3, which takes into account the influence of others on boycott motivations. The item "My friends/family encourage me to abstain from buying products from company X" was divided into 'influence from friends', 'parental influence', 'influence from siblings' and 'media influence'. The last two items were suggested by an expert in consumer behavior and Marketing scale development.

\subsection{Data collection for scale validation and reliability}

After the pretest, the items were inserted randomly into the questionnaire, which was then distributed to the respondents. The research subjects were students from two universities in the state of Rio de Janeiro, a public and a private one, both of which are located in the metropolitan area of the city of Rio de Janeiro. The questionnaire was answered by business and public administration students at the public university and by business administration students at the private university. Total number of respondents was 115 at the public university and 166 at the private university, totaling 281 answers.

To assess possible factors, we performed a factor analysis that calculated the correlation between factor loads and scale items. The factor load is a means to interpret the role of each variable in the definition of the factor (HAIR et al., 2005). We also applied the Varimax rotation method to improve the interpretation and reduce ambiguities. The KMO test (which must be greater than 0.7) and the Bartlestt test were used to assess the internal scale validity.

The difference of means test was used to assess the external validity, which shows the difference between the average values of each factor of the two groups. This is one way to assess the external validity of the factors that make up the scale. If there is significant difference between the means, a university effect is affecting the factors. If the difference is not significant, it may be inferred that there is a high degree of external validity that allows us to generalize the scale and the research results.

\subsection{Hypothesis test for gender equality in factors}

The hypothesis test defines equality in a statement that takes into account the equality of population parameters. In other words, the null hypothesis is always the one that features equality between the parameters (HAIR et al., 2005). Thus, we assumed for each factor resulting 
from the factor analysis, that $\mathrm{H}_{0}$ doesn't show any significant difference between genders, i.e., that there is equality between men and women. To accept the difference of means of gender equality as significant in the hypothesis test, the confidence interval should lie below $95 \%$ and value of $\mathrm{p} \leq 0.05$.

\section{BOYCOTT MOTIVATION SCALE VALIDATION RESULTS}

The results of the validation process of the boycott motivations scale in the Brazilian context are presented in the following section, which is divided into two parts. The first part contains an initial attempt to analyze the data and use them to make adjustment decisions. The second one presents the result of those decisions, i.e., the removal of one of the scale factors.

\section{I Data Analysis with Five Factors}

Table 1 shows the five factors clustered according to the factor analysis. The results show that the four items created after expert suggestions clustered with the items of the boycott motivations scale by Klein, Smith and John (2004). However, in their study, the scale items are clustered into four factors and some items are found in different factors than in our empirical validation study for the Brazilian context.

TABLE 1 - Factor-Item Relationship (Varimax method) with five factors

\begin{tabular}{|c|c|c|c|c|c|}
\hline \multirow{2}{*}{ Item } & \multicolumn{5}{|c|}{ Factors } \\
\hline & 1 & 2 & 3 & 4 & 5 \\
\hline My parents encourage me to abstain from buying Nike products. & .803 & .117 & .032 & -.101 & .024 \\
\hline My siblings encourage me to abstain from buying Nike products. & .792 & .020 & .104 & .199 & -.194 \\
\hline My friends encourage me to abstain from buying Nike products. & .764 & .176 & -.016 & .001 & .132 \\
\hline I would feel guilty if I bought Nike products. & -.084 & .619 & .073 & .064 & .009 \\
\hline $\begin{array}{l}\text { I would feel uncomfortable if the people that abstain from buying Nike products would } \\
\text { see me buying or consuming them. }\end{array}$ & .245 & .752 & .011 & .018 & -.063 \\
\hline $\begin{array}{l}\text { Everyone should stop buying them, because every contribution, no matter how small, is } \\
\text { very important. }\end{array}$ & .065 & .538 & .078 & -.124 & -.180 \\
\hline If the Nike child labor case were confirmed, I would stop buying their products. & .123 & .428 & .273 & -.448 & .198 \\
\hline I feel bad if I keep buying Nike products. & .396 & .603 & .107 & -.304 & .195 \\
\hline I would feel much better if I stopped buying Nike. & .389 & .616 & .081 & -.327 & .230 \\
\hline $\begin{array}{l}\text { To abstain from buying products is a very efficient way to make a company change its } \\
\text { actions. }\end{array}$ & -.084 & .375 & .444 & -.154 & -.084 \\
\hline Media reports have encouraged me to stop buying Nike products. & .259 & .141 & .810 & -.032 & .076 \\
\hline By boycotting, I can help make Nike change its decision. & -.056 & .007 & .891 & -.033 & -.025 \\
\hline I don't need to stop buying Nike, because many other people are already doing it. & -.006 & .008 & -.059 & .602 & .466 \\
\hline $\begin{array}{l}\text { I won't stop buying Nike because it's a national company and stop buying from that } \\
\text { company would make me buy imported products. }\end{array}$ & .246 & -.104 & .114 & .672 & .071 \\
\hline $\begin{array}{l}\text { One should not abstain from buying Nike products because it would jeopardize the } \\
\text { employment of many people who work at Nike. }\end{array}$ & -.115 & -.061 & -.159 & .615 & -.136 \\
\hline As I don't buy many Nike products, I boycotting that company would not be significant. & .002 & -.071 & .014 & -.032 & .865 \\
\hline
\end{tabular}

Source: Authors, based on field research data analysis 
The factors were named according to the features of their sets of items. The first factor was named 'Influence from others', since the items demonstrated the influence of others on boycott motivations. Although the 'Media influence' item was created due to suggestions of experts to check the influence of others, it was not clustered in that factor. Since that factor most impacts boycott motivations, it is understood that in the analyzed sample, the influence of people close to consumers may affect their decision to boycott a company. Table 2 contains a summary of the factors and their individual and cumulative variances.

TABLE 2 - Individual and cumulative variances of the five factors found

\begin{tabular}{ccccc}
\hline Factor & Factor name & Number of items & $\begin{array}{c}\text { Individual } \\
\text { explanation degree }\end{array}$ & $\begin{array}{c}\text { Accumulated } \\
\text { Explanation Degree }\end{array}$ \\
\hline 1 & Influence of others & 3 & $24.23 \%$ & $24.23 \%$ \\
2 & Guilt & 6 & $12.10 \%$ & $36.34 \%$ \\
3 & Boycott effectiveness & 3 & $9.12 \%$ & $45.46 \%$ \\
4 & Counterarguments & 3 & $7.46 \%$ & $52.98 \%$ \\
5 & Purchasing frequency & 1 & $6.53 \%$ & $59.46 \%$ \\
\hline
\end{tabular}

Source: the authors, based on field research data analysis.

The second factor was named 'Perception of guilt', since four items of that factor are clearly related to the perception of guilt in every respondent. Unlike the results of the 'Boycott effectiveness' factor in the study by Klein, Smith and John (2004), one of the items of that factor of their study was clustered to that second factor. The 'Everyone should stop buying them, because every contribution, no matter how small, is very important' item may be analyzed in the 'Perception of guilt' factor as the projection of the individual guilt of the consumer onto others, i.e., the feeling of guilt that a consumer expects other people may feel may be similar to his/her individual perception.

A sixth item, which addresses an issue that may encourage consumers to boycott, was also clustered to that second factor. The assumption that a company has been acting illegally or unethically, in that case child labor, could make consumers feel guilty if they kept buying its products if its illegal or unethical situation were actually confirmed. Consumers may feel guilty since they understand that purchasing products or services from that company could continue encouraging that illegal or unethical situation.

The third factor was named 'Perceived boycott effectiveness' and consists of three items, two of which are also part of the scale by Klein, Smith and John (2004). The media information item is the one that most impacts that factor. Experts suggested surveying the influence of others, i.e., this item translates the influence of the media on consumers and their boycott effectiveness perception. Here, consumers are encouraged to abstain from buying certain products when they get media information and consumers deem a boycott efficient when they receive media information or when they realize that a boycott may cause the company to change its actions or decisions.

The fourth factor was named 'counterarguments', as translated from the consumer boycott motivation scale. Three factor items of the study by Klein, Smith and John (2004) were clustered to that factor, although the original factor featured four items. The fourth item of that factor ('As I don't buy many 
Nike products, boycotting that company would not be significant') is the only item of the fifth factor, which is called 'Purchasing frequency'. In the Brazilian context, the consumers of our research may have understood this item as the frequency with which they buy Nike products and the significance of their boycott for the analyzed company.

An important result was found by the difference of means test. Regarding the external reliability of the scale (degree of generalization), the first factor (influence of others) didn't show any significant difference between the means of the consumers of the two universities $(\mathrm{F}=1.483, \mathrm{gl}=1$ and $\mathrm{p}>0.224)$, neither between the factors (Perception of Guilt and Effectiveness $-\mathrm{F}=0.087, \mathrm{gl}=1$ and $\mathrm{p}>0.768$; Boycott effectiveness $-\mathrm{F}=0.009$, $\mathrm{gl}=1$ and $\mathrm{p}>0.924$ ) and Purchasing frequency $(\mathrm{F}=3.157, \mathrm{gl}=1$ and $p>0.077)$. The absence of differences in the means of the two groups shows that these factors feature external reliability. However, factor 4 (Counterarguments) showed a significant difference between the means of the two groups $(\mathrm{F}=4.442, \mathrm{gl}=1$ and $\mathrm{p}<0.036)$, i.e., it didn't feature any external reliability. That result made it possible to test the absence of that factor in the final scale, which is presented below.

\subsection{Results obtained with four factors}

Based on that result, we analyzed the data again performing a factor analysis without the fourth factor, since it didn't show any external reliability $(\alpha=0.418)$. After that, Cronbach's alpha changed positively (increase from 0.616 to 0.678 ). Thus, a delicate decision was made by the authors and experts: the removal of the 'Counterarguments' factor from the scale adapted to the Brazilian context. That decision was taken since we realized that this factor was not externally reliable on the first attempt and since the Cronbach's alpha of the scale too low to be accepted. After removing that scale factor, Cronbach's alpha got much closer to its ideal value $(\alpha \geq 0.70)$. The final scale without the fourth factor is shown in Table 3.

It is important to note that removing the fourth factor changes the factor explanation order. With five factors, the 'guilt' dimension was the second factor. Now, the order had changed: the first factor was 'Guilt' and the second one was 'Influence of others'. The third factor was still 'Boycott effectiveness' and the fourth factor was 'Purchasing frequency'. 
TABLE 3 - Factors of the Boycott Motivations Scale in the Brazilian context

\begin{tabular}{|c|c|c|c|c|}
\hline \multirow{2}{*}{ Item } & \multicolumn{4}{|c|}{ Factor } \\
\hline & 1 & 2 & 3 & 4 \\
\hline I would feel guilty if I bought Nike products. & .436 & -.011 & .063 & -.252 \\
\hline $\begin{array}{l}\text { I would feel uncomfortable if the people that abstain from buying Nike products would see me buying } \\
\text { or consuming them. }\end{array}$ & .655 & .271 & .002 & -.296 \\
\hline $\begin{array}{l}\text { Everyone should stop buying them, because every contribution, no matter how small, is very } \\
\text { important. }\end{array}$ & .732 & .105 & .144 & -.102 \\
\hline If the Nike child labor case were confirmed, I would stop buying their products. & .670 & -.012 & .243 & .218 \\
\hline I would feel much better if I stopped buying Nike. & .815 & .217 & .046 & .202 \\
\hline I feel bad if I keep buying Nike products. & .765 & .259 & .064 & .187 \\
\hline My friends encourage me to abstain from buying Nike products. & .231 & .773 & -.026 & .139 \\
\hline My parents encourage me to abstain from buying Nike products. & .195 & .799 & .037 & .109 \\
\hline My siblings encourage me to abstain from buying Nike products. & -.015 & .820 & .094 & -.230 \\
\hline By boycotting, I can help make Nike change its decision. & .027 & -.050 & .897 & -.017 \\
\hline To abstain from buying products is a very efficient way to make a company change its actions. & .392 & -.098 & .445 & -.145 \\
\hline As I don't buy many Nike products, I boycotting that company would not be significant. & .027 & .026 & .009 & .860 \\
\hline
\end{tabular}

Factor 1 - Perception of guilt; Factor 2 - Influence of others; Factor 3 - Boycott efficiency; Factor 4 - Purchasing frequency Source: the authors.

\subsection{Scale Reliability and Validity}

Scale reliability and validity findings presented here result from data collection performed in the second step of our research with subjects from two different higher education institutions. Unlike the pretest, both the $\mathrm{KMO}$ test (0.783) and Cronbach's alpha of the 13 scale items ( $\alpha=0.678)$ were significant and acceptable (HAIR et al., 2005). As in the pretest and in the preceding stage featuring five factors, the Bartlestt test was also significant (1019.047), which shows that the sample was sufficient. Grouped into four different factors, those 13 items explain 63.3\% of the variability (Table 4). In other words, the scale that resulted from the translation and the reverse translation performed by experts and the inclusion of items suggested by marketing scales experts feature internal reliability $(\alpha=0.678)$ and explain $63.3 \%$ of the variability.

TABLE 4 - Individual and cumulative variances of the four factors found

\begin{tabular}{ccccc}
\hline Factor & Factor name & $\begin{array}{c}\text { Number of } \\
\text { items }\end{array}$ & $\begin{array}{c}\text { Degree of individual } \\
\text { explanation }\end{array}$ & $\begin{array}{c}\text { Degree of accumulated } \\
\text { explanation }\end{array}$ \\
\hline 1 & Guilt & 6 & $30,59 \%$ & $30,59 \%$ \\
2 & Influence from others & 3 & $13,28 \%$ & $43,87 \%$ \\
3 & Boycott efficiency & 3 & $10,71 \%$ & $54,59 \%$ \\
4 & Purchasing frequency & 1 & $8,70 \%$ & $63,30 \%$ \\
\hline
\end{tabular}

Source: the authors, based on field research data analysis. 
To validate the scale, we had to develop the construct validity by means of the discriminant validity. According to McDaniel and Gates (2006, p. 290), the discriminant validity aims to find "a low degree of correlation between supposedly different constructs." The factors were first validated for being discriminant in each factor and then, more importantly, because their Cronbach's alpha was greater than 0.6 (HAIR et al., 2005) when each factor was analyzed individually, which shows to be acceptable. In other words, when the factors were analyzed separately, the correlation among the items of each factor was acceptable. Table 5 features Cronbach's alphas of the items of each factor - including the 'counterarguments' factor to demonstrate that it produced an unreliable result $(\alpha \leq 0.60)$.

TABLE 5 - Factor Validity Statistics

\begin{tabular}{lcc}
\hline Factors & Cronbach's alpha & Number of items \\
\hline All items & 0,616 & 16 \\
Factor "Influence from others" & 0,755 & 3 \\
Factor "Guilt" & 0,65 & 6 \\
Factor "Boycott Efficiency" & 0,601 & 3 \\
Factor "Counterarguments" & 0,418 & 3 \\
Factor "Purchasing frequency" & - & - \\
\hline
\end{tabular}

Source: the authors, based on field research data analysis.

\subsection{Hypothesis test for the difference between genders and the 'perception of guilt' factor}

During the data tabulation process of the initial work, i.e., the validation of the boycott motivations scale by Klein, Smith and John (2004), we analyzed that the majority of the people who boycotted Nike after having received information on semi-slave and child labor were women. To verify that behavior, simple descriptive statistics were performed to find out if there was a percentage difference between men and women or if that relationship didn't exist.

The survey of the people who boycotted Nike after they had had access to information on abusive practices of Nike's supply chain showed that $35.21 \%$ of the women who had received that information stopped buying Nike products. Men accounted for a lower value, i.e., $20.28 \%$, as shown in Table 6.

TABLE 6 - Percentage of men and women who boycotted Nike after having received negative information on that company.

\begin{tabular}{|c|c|c|c|c|}
\hline \multirow{5}{*}{ Gender } & \multicolumn{4}{|c|}{ Have you already had access to negative information on Nike? } \\
\hline & \multicolumn{4}{|c|}{ Yes } \\
\hline & \multicolumn{4}{|c|}{ Have you decided to abstain from buying Nike due to negative information on that company? } \\
\hline & Yes & No & Yes & No \\
\hline & Absolute value & Absolute value & Percentage & Percentage \\
\hline Male & 14 & 55 & $20 \%$ & $80 \%$ \\
\hline Female & 25 & 46 & $35 \%$ & $65 \%$ \\
\hline Total & 39 & 101 & $28 \%$ & $72 \%$ \\
\hline
\end{tabular}

Source: the authors, based on field research data analysis. 
However, such differences cannot be presented as statistical data of the sample, or a survey of inferences, or a presentation of causality relations with the factors. It would be too simple to state that women are more likely to boycott than men based on scale validation. To do so, in order to reinforce our results, we performed a hypothesis test to find out if the mean difference between men and women would be significant for each of the factors, as per Table 7.

TABLE 7 - Hypothesis test for differences between genders in each factor (ANOVA)

\begin{tabular}{|c|c|c|c|c|c|c|}
\hline & & Sum of squares & GL & Mean square & F Test & Sig. \\
\hline \multirow{3}{*}{ Guilt } & Among groups & 9.207 & 1 & 9.207 & 9.566 & .002 \\
\hline & In groups & 243.505 & 253 & .962 & & \\
\hline & Total & 252.712 & 254 & & & \\
\hline \multirow{3}{*}{ Influence of others } & Among groups & .556 & 1 & .556 & .553 & .458 \\
\hline & In groups & 254.045 & 253 & 1.004 & & \\
\hline & Total & 254.600 & 254 & & & \\
\hline \multirow{3}{*}{ Boycott efficiency } & Among groups & .236 & 1 & .236 & .235 & .628 \\
\hline & In groups & 254.559 & 253 & 1.006 & & \\
\hline & Total & 254.795 & 254 & & & \\
\hline \multirow{3}{*}{$\begin{array}{l}\text { Purchasing } \\
\text { frequency }\end{array}$} & Among groups & 1.433 & 1 & 1.433 & 1.430 & .233 \\
\hline & In groups & 253.559 & 253 & 1.002 & & \\
\hline & Total & 254.992 & 254 & & & \\
\hline
\end{tabular}

Source: the authors, based on field research data analysis.

Table 7 shows that after the scale validation process and the individual analysis of the factors, the only factor that showed a significant difference with a confidence interval of $95 \%$ was 'Perception of guilt' when the gender difference hypotheses were tested. It can be inferred that in our sample, woman felt guiltier than man about the Nike boycott. That result corroborates the results of international studies, such as Neilson (2010), Stolle, Hogge and Micheletti (2005), and Barda and Sardianou (2010), in which gender differences were found regarding consumer boycott intentions or acts.

\section{CONTRIBUTIONS OF THE STUDY, DEVELOPMENTS AND SUGGESTIONS FOR FUTURE RESEARCH}

As discussed in the theoretical framework of this research, the literature contains few empirical results that highlight gender differences regarding the abstention from buying products, services, or brands of a given company. In Brazil, a $2 \times 2 \times 2$ factorial experiment performed by Cruz (2013a) resulted in no difference between men and women, neither for the 'boycott intention' variable (BI), nor for the 'perceived boycott effectiveness' variable (PBE). However, that author states that one of the features of experiments is that their results cannot be generalized. Our study shows clearly and empirically that there is a significant difference between men and women regarding their feeling of guilt after receiving information about abusive actions of a company or its partners. Women were motivated by their feeling of guilt, which functions as a cause factor, in abstaining from buying Nike products.

Although the three factors have not shown any significant and positive differences between the means of men and women, the main factor found in the factor analysis (perception of 
guilt), the one that explains most of the model variance, is the factor that may be influenced by the 'Gender' variable, as shown empirically by our study. In other words, women felt guiltier than men, which shows that in this sample, this variable is relevant regarding consumer boycott motivations.

That result led to two important developments in this study, which are presented below: (i) the contextualization of guilt in contemporary women and (ii) the influence of that context on the perception of guilt in women. These items are detailed below as topics, since the empirical research results made the authors aware of how important it is to seek epistemological arguments in the fields of psychology and anthropology to understand that significant difference in the empirical results of the boycott in relation to guilt. It is therefore wiser to present those theoretical arguments in this section as development of the empirical results of the emerging dimension of the scale validation rather than to present them in the theoretical background section, since other variables were analyzed in previous studies, such as boycott intention, boycott effectiveness perception (CRUZ, 2013a), inclination to boycott (KLEIN, SMITH, JOHN, 2004) and political consumption (NEILSON, 2010), but not the 'Perception of guilt' construct, which results from the scale validation.

\section{I Historical and theoretical contextualization of the self-perception of guilt in contemporary women}

In the final stage of the Neolithic period (between 4400 and $2900 \mathrm{BC}$ ), the concepts of power, affiliation and inheritance were becoming imperatively masculinized and women valuable commodities, suppliers of future labor, which shows that the female gender was gradually losing its power (EISLER, 1989; LINS, 2007). Women then become exclusively male property and inheritance is only devised to legitimate sons.
With the impacting discovery of paternity, the phallic principle (the ideology of male supremacy) conditions the way of living of humanity and generates patriarchy - a social organization based on the power of the father, whose descendants and kinship exclusively take into account the male lineage. Women were considered inferior to men, were subordinate to their domination (LINS, 2007; EISLER, 1989). The establishment of patriarchy in Western civilization takes place between 3100 and 600 BC.

Patriarchy (in the context of controlling women's fertility and the sexual division of labor) features three points of conditioning that are essential to its oppressive dominance over women: (i) the control of fidelity - used by men to protect and legitimize their heritage, treating women as suspects, patronized subjects, uninteresting and incompetent relationship partners; (ii) control of children - idealized rightful heritage, whose good development is only recognized as a merit of the father, and whose surname they customarily and lawfully adopt, unconsciously reinforcing the idea that both the mother and the children are properties of the father; (iii) the control of sexuality - women were used as social objects and exclusively defined by their relationship with their husbands. Positive inferences on their self-esteem were prohibited, they were taught to deny their bodies and beauty, since those are instruments of self-worth (KREPS, 1992; LINS, 2007).

According to Lins (2007), Western cultures live in a state of normality under patriarchy. That normality is based on two cornerstones: religion (mainly based on the Bible) and science. The Bible is a collection of Judeo-Christian books written by many people over the course of more than a thousand years, starting approximately in 1450 BC. Its influence on the West, including on the unconscious of people, is undeniable. Its coercive power on guilt (through the idea of sin) is strong and is a perfect element to corroborate the foundations of the questioning based on our data analysis of the scale validated by our study, which shows a self-perception of guilt that's greater in 
women than in men (in the boycott context). Given the fact that Brazil is a religious country, the Brazilian population, too, is the result of that Judeo-Christian culture, in which guilt prevails in the social unconscious. It has therefore become virtually impossible to escape the influence of that agonizing guilt (even non-Christian individuals are inserted in contexts of 'sin' and 'guilt').

The Bible consistently depicts women as the source of sin and degradation. In female biblical figures (which guaranteed the patronizingly superior attitude of God and men), symbols of the denial of sex, women are configured as the scapegoat of humanity, occupying a position of "lower" in relation to men (KREPS, 1992, FEUERSTEIN 1994; LINS, 2007). Even the later biblical figure of Mary, a small attempt to revalue women, has been a failed initiative - as the rejection of her importance is clearly shown by her position in masses, prayers and popular imagery of her strength -, masked by submissive and subservient patience toward her husband and son.

Women represented directly and indirectly the source of all the problems of humanity and the conditioning of the past centuries forced them to live in constant shame for the simple fact of being a woman and in deep penance toward humanity, since they had caused the countless problems of the world (RUSSEL, 1955; LINS, 2007). Thus, the Bible ultimately dominates, enslaves, and continually devaluates women in its texts, degrading their position.

Thus, the influence of the Judeo-Christian culture, in a context of syncretism of Hebrew and Roman customs with those of the Near East, defines women as fragile, false and emotionally unstable - which explains the transition of the female figure from "primarily influential and essential" to "property of the father, the husband and the son". Motherhood is her only form of sexual expression, intrinsically linked to pain, creating a concept of suffering and self-punishment for being a woman (FEUERSTEIN, 1994). It is precisely that historical and cultural context that helps us to understand the relationship between perception of guilt and gender, as the socially created context assigned to women was always inferior or submissive, historically creating a guilty social subject, responsible for the failures of men. This analysis is essential to understand the construct of the perception of guilt in relation to consumer boycotts.

\subsection{Psychoanalytic conceptualization of guilt and its relationship to gender differences}

'Guilt' is the painful awareness that we have somehow harmed others (objects), felt by the person itself (SEGAL, 1975). Melanie Klein (1970), the renowned child psychologist, states that the development of the feeling of guilt starts in individuals as soon as the baby attacks the (originally) maternal figure, ambivalently loved and hated because it is initially his first and unique environmental reference, generating as much pleasure as displeasure, which is part of the subject's differentiation process of the world.

Those moments (called "depressive positions") symbolized by the child result in a context of great anxiety (causing psychological suffering due to the distressing perception of the conflict between love and hate of the parental figure), since it leads to a possible loss of that figure (externally and internally). The child therefore takes repair actions so as not to lose its loved object (KLEIN, 1970; 1974).

Thus, over time, the child introjects its parental figures and the ambivalence and guilt felt towards them, i.e. it internalizes them and marks them as internal behavioral reference points. That introjection makes it possible to create the superego, a psychological construct of moral nature (and therefore social), repressor of behaviors and creator of social adaptation in individuals (SPILLIUS, 1990; SEGAL, 1975).

By relating that psychological construct in subjects to the historical and cultural bases previously presented (such as patriarchy, which denotes a strong introjection of the father figure 
in women), we may draw a line of thought that corroborates a more intense self-perception of guilt in women than in men, caused by the impressive father figure and the temporal control established by men over women.

In our study, within the interrelationship between the 'perception of guilt' construct based on our data analysis and the Kleinian guilt concept presented above, it becomes clear that the possibility of causing some kind of damage to one or more individuals who make up the consumer's group, women are subject to greater self-awareness of guilt and experience the anxiogenic elements arising from that perception. That anxiety then forces the subject to take action aimed at maintaining a certain behavior - the boycott.

Given women's historical submission and lack of social role, and correlating that to the difference observed in the 'perception of guilt' construct that resulted from the validation of the scale that was part of the field research of our study, we found that those feelings of anxiety and guilt caused by that constellation (through introjected parental figures, especially male ones) cause more intense guilt conflicts in women than in men. That finding is supported by the items developed by our study that allowed including the 'perception of guilt' construct into the validated scale. That construct is not originally part of the study by Klein, Smith and John (2004), which provides insights for future research related to the issue of consumer boycotts or, more specifically, to the difference in 'Perception of guilt' and 'Gender' .

\subsection{Theoretical and practical implications, and future research}

The validation of the 'Perception of guilt' construct by our study provides theoretical and practical contributions related to consumer boycott. Theoretical implications include: (i) the 'consumer gender' vs. 'boycott' issue, since there are few studies that present an empirical verification of those variables; (ii) the theoretical psychoanalytical analysis conducted after the development of the 'Perception of guilt' construct to verify an epistemological basis that justifies the relationship of the construct with a greater predisposition to guilt of women than men, and (iii) enable other researchers to use the scale validated by our research to replicate our study in other groups or associate it to other variables - e.g., identify which type of boycott (ecological, social, minority, religious, or economic) scores higher in the 'Perception of guilt' of consumers.

Regarding practical implications, two different analysis perspectives of 'Perception of guilt' and 'Gender' emerge, namely: (i) communication strategies with consumers or former consumers, and (ii) diagnosis of corporate image among women or men. Regarding communication strategies, as women feel guiltier than men regarding boycotts, the development of tools that aim to reconcile consumers and companies could, e.g., take into account the more intrinsic aspects of the psychotherapeutic trend of women may be an effective strategy for crisis management processes of consumer boycott situations. With regard to the diagnosis of the corporate image among men and women, women may assess a company negatively due to the fact that they feel guiltier than men and thus influence other consumers, making them stop buying products from that company, which eventually would result in tangible and intangible losses regarding both company image and its reputation.

The scale validation results of our article, as well as the psychoanalytic approach of guilt presented as a development of the scale validation and the theoretical and practical implications of this research lead to other research questions, as shown in Chart 3. 


\begin{tabular}{|c|c|c|}
\hline Problem & Objective & Possible result \\
\hline $\begin{array}{l}\text { Boycotting women and company } \\
\text { actions to retain women who } \\
\text { abstain from buying. }\end{array}$ & $\begin{array}{l}\text { Survey possible actions that a company } \\
\text { might take to win back former } \\
\text { consumers. }\end{array}$ & $\begin{array}{l}\text { Open, due to the fact that this is a } \\
\text { qualitative exploratory study. }\end{array}$ \\
\hline $\begin{array}{c}\text { Religion and Perception of guilt in } \\
\text { boycotts. }\end{array}$ & $\begin{array}{c}\text { Find out if religious women feel guiltier } \\
\text { than atheists. }\end{array}$ & $\begin{array}{c}\text { Religious women feel guiltier than } \\
\text { atheists. }\end{array}$ \\
\hline $\begin{array}{l}\text { Business area of the company and } \\
\text { perception of guilt of women. }\end{array}$ & $\begin{array}{l}\text { Find out if the business area of a given } \\
\text { company alters the perception of guilt } \\
\text { of women. }\end{array}$ & $\begin{array}{l}\text { Segments that operate exclusively } \\
\text { for the female audience feature } \\
\text { lower perception of guilt than other } \\
\text { segments. }\end{array}$ \\
\hline Perception of guilt and education. & $\begin{array}{l}\text { Find out if the Perception of guilt } \\
\text { increases proportionally to the years of } \\
\text { schooling. }\end{array}$ & $\begin{array}{l}\text { Consumers with a higher } \\
\text { educational level feature a higher } \\
\text { perception of guilt than those with } \\
\text { a lower educational level. }\end{array}$ \\
\hline $\begin{array}{l}\text { Perception of Guilt, Gender and } \\
\text { Ecological boycott. }\end{array}$ & $\begin{array}{l}\text { Identify whether women feature a } \\
\text { higher perception of guilt than men in } \\
\text { ecological boycotts. }\end{array}$ & $\begin{array}{l}\text { Women tend to score higher } \\
\text { in Perceived guilt than men in } \\
\text { Ecological boycotts, due to the } \\
\text { anxiogenic elements of guilt. }\end{array}$ \\
\hline
\end{tabular}

CHART 3 - Suggestions for further research

Source: the authors.

To conclude, we deem our article relevant for the area of Consumer Behavior in Brazil, since it not only discusses with scientific rigor the validation of a Boycott motivations scale in Brazil and the developments of constructs found in this process in relation to the gender of the consumer, but it also seeks historical, psychological and anthropological developments that underlie the empirical and statistically significant difference found in consumers who participated in the sample. Moreover, by presenting proposals for future research, the authors highlight the knowledge gaps that permeate the subject of consumer boycott.

\section{NOTAS}

1. To avoid confusing the sense of the term and the comparison with the term boycott, we decided not to translate buycott into Portuguese, since those terms can be compared. Neilson (2010) states that buycott can be understood as consumers rewarding companies by buying their products for behavior consistent with their goals. Both boycott and buycott are used to define a form of political consumption. 


\section{REFERENCES}

AAKER, D. J. Leveraging the corporate brand. California Management Review, Berkeley, v. 46, n.3, p. 6-18, Spring 2004.

BARDA, C.; SARDIANOU, E. Analysing consumers' 'activism' in response to rising prices. International Journal of Consumer Studies, Oxford, v. 34, n. 2, p. 133-139, Mar. 2010.

CRUZ, B. P. A. O boicote no comportamento do consumidor. 2013. 192 f. Tese (Doutorado em Administração de Empresas)-Escola de Administração de Empresas de São Paulo, Fundação Getúlio Vargas, São Paulo, 2013a.

Boicote de consumidores: demarcação de conceitos e casos no Brasil. Revista de Administração do Gestor, Piedade, RJ, v. 3, n. 1, p. 61-73, jul. 2013b.

Boicote de consumidores em relação à responsabilidade social corporativa. In: ENCONTRO NACIONAL DE PROGRAMAS DE PÓS-GRADUAÇÃO EM ADMINISTRAÇÃO, 35., 2011, Rio de Janeiro. Anais... Rio de Janeiro: Anpad, 2011.

DEVELLIS, R. F. Scale development: theory and applications. 2nd ed. California, USA: Sage Publications, 2003.

EISLER, R. O cálice e a espada: nossa história, nosso futuro. Rio de Janeiro: Imago, 1989.

FEUERSTEIN, G. A sexualidade sagrada. Rio de Janeiro: Siciliano, 1994.

FRIEDMAN, M. Consumer boycotts: effecting change trough the marketplace and the media. New York: Routledge, 1999.

THE GIRLCOTT. History. c2009. Disponível em: <http://www.thegirlcott.com/history.shtml>. Acesso em: 12 nov. 2011.
KALSON, S. Information age breeds boycotts by the score. Pittsburgh Post-Gazette, Pittsburgh, 8 Nov. 2005. Disponível em: <http://news.google. $\mathrm{com} /$ newspapers? $\mathrm{nid}=1129 \& \mathrm{dat}=20051108 \&$ $\mathrm{id}=$ eolIAAAAIBAJ $\&$ sjid $=33$ ADAAAAIBAJ $\&$ pg=2458,5590445 >. Acesso em: 13 nov. 2011.

HAIR, J. F. et al. Análise multivariada de dados. Porto Alegre: Bookman, 2005.

KLEIN, J. G.; SMITH, N. C.; JOHN, A. Why we boycott: consumer motivations for boicott participation. Journal of Marketing, Binghamton, v. 68, n. 3, p. 92-109, July 2004.

KLEIN, M. Amor, ódio e reparação. Rio de Janeiro: Ed. Imago, 1970.

Inveja e gratidáo. Rio de Janeiro: Ed. Imago, 1974.

KNIGHT, R. F.; PRETTY, D. I. Brand risk management in a value context. Oxford: Oxford University, 2000. (Templeton Briefing; v. 5)

KREPS, B. Paixóes eternas, ilusóes passageiras. Rio de Janeiro: Saraiva, 1992.

LINS, R. N. A cama na varanda: arejando nossas ideias a respeito de amor e sexo. Rio de Janeiro: Ed. BestSeller, 2007.

MCDAniel, C.; GATES, R. Pesquisa de marketing. São Paulo: Thompson Learning, 2006.

NEILSON, L. A. Boycott or buycott? Understanding political consumerism. Journal of Consumer Behavior, [S.1.], v. 9, n. 3, p. 214-227, May/June 2010.

PALAZZO, G.; BASU, K. The ethical backlash of corporate branding. Journal of Business Ethics, Dordrecht, v. 73, n. 4, p. 333-346, July 2007.

RUSSEL, B. O casamento e a moral. Rio de Janeiro: Ed. Nacional, 1955. 
SEGAL, H. Introdução à obra de Melanie Klein. Rio de Janeiro: Ed. Imago, 1975.

SOULE, S. A. Contention and corporate social responsibility. Oxford: Cambridge University Press, 2009.

SPILlius, E. B. Melanie Klein hoje: desenvolvimento da teoria e técnica. Rio de Janeiro: Editora Imago, 1990. v. 2.
STOLLE, D.; HOOGUE, M.; MICHELETTI, M. Politics in the supermarket: political consumerism as a form of political participation. International Political Science Review, London, v. 26, n. 3, p. 245-269, July 2005. 